\title{
Gender Based Waste Management Model in Sei Sembilang, Banyuasin Regency, South Sumatera Province
}

\author{
By: \\ Wijaya Hadi Asmara ${ }^{1^{*}}$, Sarno $^{2}$, Nengyanti ${ }^{3}$ \\ ${ }^{1}$ Environmental Management Study Program, Graduate School, Universitas Sriwijaya. Jl. Padang Selasa No. \\ 524, Bukit Besar, Palembang, 30139, Sumatera Selatan, Indonesia \\ ${ }^{2}$ Department of Biology, Faculty of Mathematics and Natural Sciences, Universitas Sriwijaya. Jl. Raya \\ Palembang - Prabumulih Km. 32, Indralaya, Ogan Ilir, 30662, Sumatera Selatan, Indonesia \\ ${ }^{3}$ Demography Study Program, Graduate School, Universitas Sriwijaya. J1. Padang Selasa No. 524, Bukit Besar, \\ Palembang, 30139, Sumatera Selatan, Indonesia \\ *E-mail: wijayaasmara76@gmail.com
}

\begin{abstract}
Waste is one of the major problems in Sei Sembilang, a hamlet located in the Berbak-Sembilang National Park (BSNP) area. The area is difficult to reach, and to date, there is no effective waste management system applied. Waste management cannot be separated from the involvement of men and women; hence, a model that can accommodate the community's interests and how gender plays a role in that model is needed. This study aims to develop an appropriate gender-based waste management model to overcome these problems. The study was conducted using mixed methods of Sequential Explanatory. Quantitative data were analyzed through 3 stages: editing, coding, and tabulation in tables and diagrams. Qualitative data were analyzed descriptively through 3 stages, that are reduction, presentation, and verification. The results showed that the community's knowledge and attitudes, both men and women, were relatively high, but not accompanied by their behavior. Women tend to have a higher level of knowledge, attitudes, and behavior than men. The waste management model that can be developed is an integrated waste management model that can accommodate all society levels. This model divides roles between the community, government, and the private sector. In this model, women have a more significant role in separating waste and recycling plastic waste into handicraft products. Men play a role in transporting and processing plastic waste into economically valuable plastic raw materials.
\end{abstract}

Keyword: Berbak-Sembilang National Park, gender, waste management model

\section{INTRODUCTION}

The mangrove ecosystem is one of the important coastal area resources in the life of humans and other living creatures. However, currently those functions are disrupted by human activities, i.e., careless littering. Most of the waste in the mangrove comes from household waste thrown to the rivers and ends at the estuary, which has become such a phenomenon in Sei Sembilang Hamlet. Waste is a major issue for the community, where there has not been any effective waste management leading to the accumulation of garbage in residential areas. The condition of Sei Sembilang Hamlet, which is challenging to reach and located inside the Berbak-Sembilang National Park (BSNP), results in the absence of waste disposal and waste management system, similar to the common cases in urban areas.

Less optimum waste management systems cause people to throw garbage into the rivers, sea, or underneath residents. In addition to causing the settlement to look dirty and creating a source of diseases in society, it also impacts the surrounding environment. Based on data 
obtained from YPI (2017), inorganic waste collected for five months was recorded at $644.5 \mathrm{~kg}$, with $90 \%$ of the dominant type of waste being plastic wastes. Plastic waste that is thought to have originated from the hamlet community's household activities has resulted in accumulation in the mangrove forest's mouth in the BSNP area. A sad sight commonly found in mangrove ecosystems is a large amount of solid waste such as plastic, cork, glass, and cardboard that has piled up and stuck in mangrove roots (Williams and Simmons 1996; Winata and Yuliana 2016).

The waste problem can cause problems for the community and threaten the ecosystem in BSNP, mainly in mangroves' ecology in coastal areas. The results of Sidik (2016) stated that waste is the main enemy of mangrove forests which can cause the death of mangrove seedlings. This rubbish can kill the mangrove tree when the garbage is wrapped around the mangrove tree trunks because it can rot. This problem becomes critical and needs to be resolved because the waste issues affect society and threaten ecosystems in the BSNP area.

An integrated waste management model is required to solve waste issues in Sei Sembilang Hamlet. Waste management in Sei Sembilang hamlet will reduce the pressure of waste on mangroves in BNSP. The development of a waste management model is based on the division of men and women's roles. Based on research conducted by Talalaj and Walery (2015), gender affects the quantity of waste. Women and the environment were naturally bound (Su et al. 2019). The research result of Wijayanti et al. (2019) stated that women and households are two inseparable things. Because $50 \%$ of waste comes from households, women, and families are expected to play the role of controlling the environment (Wijayanti et al. 2019).

Developing an integrated waste management model that can accommodate all levels of society requires a comprehensive study of the community's characteristics and level of knowledge, attitude, and behavior related to waste and its management. This study examines the community's level of knowledge, attitudes, and behavior in waste management and appropriate gender-based waste management models to overcome waste issues in Sei Sembilang Hamlet, Banyuasin, South Sumatera.

\section{MATERIALS AND METHOD}

\section{Time and Location of Research}

The study was conducted in October 2019 until December 2019 in Sei Sembilang Hamlet, Sungsang IV Village, Banyuasin II Sub-District, Banyuasin Regency, South Sumatera Province. Sei Sembilang Hamlet is located in the Traditional Zone (Figure 1) of the Berbak-Sembilang National Park (BSNP) Utilization area and Sanjang River flow. Sei Sembilang Hamlet is an enclave area within BSNP. The community in the Sei Sembilang area are indigenous people from the Sungsang tribe who had come and occupied the Sei Sembilang area before it was designated as a Sembilang National Park in 2003.

\section{Data Collection}

The social data collection was conducted using Explanatory Sequential Mixed Method (Cresswell 2016). The approach aims to add qualitative information to quantitative data to enrich the data and better understand the social phenomena studied (Singarimbun and Effendi 2019). Primary data is generated to obtain field data and information using several methods, i.e., structured interviews (questions through a questionnaire), in-depth interviews, and observation. The survey method was conducted to obtain data on the respondents' social, economic, demographic characteristics, community knowledge, attitudes, and behavior to waste management in the BSNP area. 


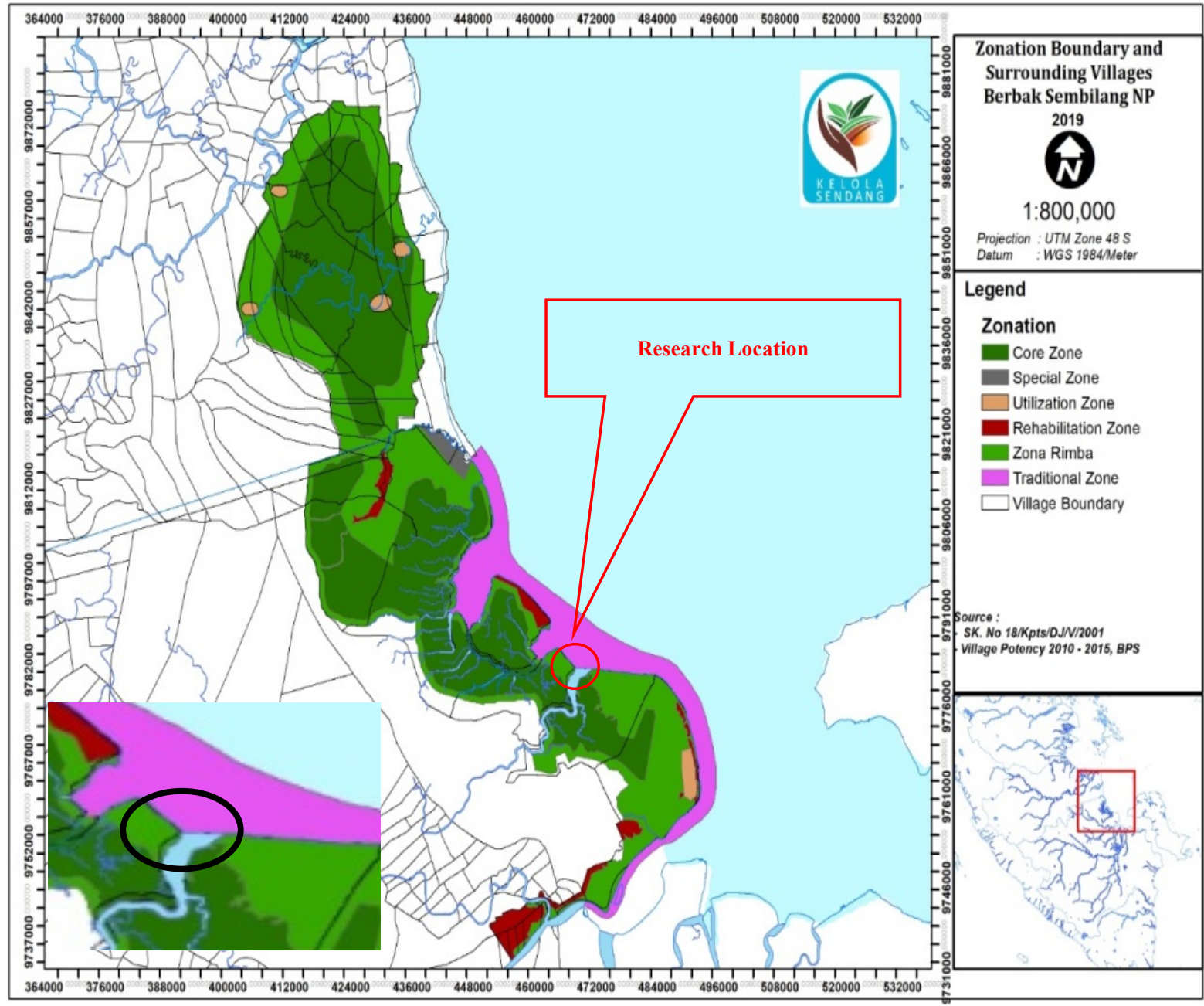

Figure 1. Location of study in the traditional zone of BSNP area.

In-depth interviews were conducted with key informants; they are village heads, hamlet heads, heads of waste banks, and community leaders. Focus group discussion (FGD) was held with 30 people consisting of 21 people from community group representatives, 6 people from the village government, and 3 people National Park managers. Observations were utilized to support quantitative data and a more comprehensive explanation of the qualitative data findings. Apart from primary data, this study also uses secondary data obtained from literature and documentation studies.

The number of respondents for structured interviews in this study is calculated based on Krejcie and Morgan (1970) :

$$
n=\frac{N X^{2} P(1-P)}{\left((N-1) d^{2}\right)+X P(1-P)}
$$

where $n=$ sample size; $N=$ population size (372 households); $P=$ proportion (opportunity function) of population $(0.5) ; d=$ estimated error $(10 \%) ; \chi^{2}=$ chi-squared for degrees of freedom (3.841).

The number of respondents in this study was obtained as many as 76 respondents. Because of the number of men and women in Sei Sembilang Hamlet does not significantly differ (YPI 2017), the respondents were divided into two groups, men and women. Each respondent group consists of 38 males and 38 females. 


\section{Data Analysis}

The data from the study result was analyzed in quantitative and qualitative manners. Quantitative data processing was carried out in several stages, i.e., editing, coding, and creating tabulations in compiling process and data analysis in tables and diagrams. The data processed is then analyzed using quantitative analysis. The quantitative analysis in this study used a descriptive analysis approach (Singarimbun and Effendi 2019). In the qualitative approach, data analysis is performed through 3 stages (Cresswell 2016), i.e., data reduction, data presentation, and verification. The qualitative data is used to support quantitative data and develop a waste management model to be applied in Sei Sembilang Hamlet.

The data were obtained from the FGD process used to determine the activity profile, community access, and control and the benefits and impacts of waste management in mangrove conservation. To facilitate the series of research activities carried out, an outline can be described in table 1.

Table 1. Data collection techniques.

\begin{tabular}{|c|c|c|c|c|c|}
\hline No. & Variable & Indicator & Research Method & Data Source & Data Analysis \\
\hline 1 & $\begin{array}{l}\text { Characteristics } \\
\text { of waste }\end{array}$ & $\begin{array}{l}\text { Types of waste, } \\
\text { waste volume, } \\
\text { frequency of } \\
\text { disposing of } \\
\text { waste }\end{array}$ & $\begin{array}{l}\text { Questionnaire, } \\
\text { observation, in- } \\
\text { depth interview }\end{array}$ & $\begin{array}{l}\text { Respondents, key } \\
\text { informant }\end{array}$ & $\begin{array}{l}\text { Quantitative and } \\
\text { qualitative }\end{array}$ \\
\hline 2 & $\begin{array}{l}\text { Social and } \\
\text { Economic } \\
\text { Characteristics }\end{array}$ & $\begin{array}{l}\text { Age, number of } \\
\text { family members, } \\
\text { education, type of } \\
\text { job, income }\end{array}$ & Questionnaire & Respondents & $\begin{array}{l}\text { Quantitative and } \\
\text { qualitative }\end{array}$ \\
\hline 3 & $\begin{array}{l}\text { Knowledge, } \\
\text { attitudes, and } \\
\text { behavior related } \\
\text { to waste } \\
\text { management }\end{array}$ & $\begin{array}{l}\text { Knowledge: } \\
\text { general } \\
\text { knowledge about } \\
\text { waste, knowledge } \\
\text { of the impact of } \\
\text { waste, sorting } \\
\text { waste, waste } \\
\text { processing, waste } \\
\text { recycling, final } \\
\text { waste processing. } \\
\text { Attitudes: } \\
\text { waste collection, } \\
\text { generation, } \\
\text { transport, sorting, } \\
\text { reuse, recycling, } \\
\text { processing. } \\
\text { Behavior: } \\
\text { Waste disposing } \\
\text { habit, collection, } \\
\text { sorting, reuse, } \\
\text { transportation, } \\
\text { participation }\end{array}$ & $\begin{array}{l}\text { Questionnaire, in- } \\
\text { depth interview }\end{array}$ & Respondents & $\begin{array}{l}\text { Quantitative and } \\
\text { qualitative }\end{array}$ \\
\hline 4 & $\begin{array}{l}\text { Waste } \\
\text { Management } \\
\text { Model }\end{array}$ & Participation & FGD & $\begin{array}{l}\text { community } \\
\text { groups, } \\
\text { village } \\
\text { government, and } \\
\text { BSNP } \\
\text { management. }\end{array}$ & Qualitative \\
\hline
\end{tabular}

Variable knowledge, attitudes, and behavior related to waste management were analyzed using the Harvard Analytical Framework (RECOFTC 2015) to determine gender 
roles in each variable. The Harvard Analytical Framework addresses the question of 'who does what'. The survey was conducted to determine gender-specific roles in waste management activities for all productive, reproductive, and community tasks.

\section{RESULT AND DISCUSSION}

Waste is a solid waste consisting of organic or non-organic substances or materials that no longer have benefits and must be appropriately managed to not damage the environment (Kastaman et al. 2007). Littering is not the only potential to damage the neighborhood, but also may damage the environment. Like in Sei Sembilang Hamlet, the community's habit of littering may damage and impact the environment and potentially damage the surrounding mangrove ecosystem in BSNP. Knowledge on the characteristics of the waste is required to formulate proper waste management, either in terms of type or volume of the waste in the research location, the social, economic, and demographic characteristics of the society, as well as the community knowledge, attitudes, and behavior in the current waste management and mangrove conservation.

\section{Characteristics of the waste in Sei Sembilang Hamlet area}

Based on the original materials, Sucipto (2012) divides waste into two types, i.e., organic and inorganic waste. Organic waste is the waste produced from food scraps, while inorganic waste is the waste that cannot be decomposed naturally. However, for the marine waste in marine debris survey monitoring of NOAA (2013), waste is divided into several types that represent all of the materials, i.e., plastics, metal, glass, rubber, wood, and clothes/fiber (Patuwo et al. 2020).

The study result shows that the amount of organic and inorganic waste produced in Sei Sembilang Hamlet was $83.8 \%$ and $16.2 \%$, respectively. Organic waste is the waste produced from food scraps, while inorganic waste is the type of marine waste where most of them are found in the form of plastics of 58.7\% and glasses of $17.5 \%$ (Table 2).

Table 2. Type of household waste in Sei Sembilang Hamlet.

\begin{tabular}{clclc}
\hline No & Type of waste & Percentage (\%) & Waste Format & Percentage (\%) \\
\hline 1 & Organic & 83.8 & Food scraps & 100.0 \\
2 & Inorganic & 16.2 & Plastics & 58.7 \\
& & & Styrofoam & 9.0 \\
& & Metal & 4.4 \\
& & & Glass & 17.5 \\
& & & Rubber & 10.3 \\
\hline
\end{tabular}

Plastic waste is the most inorganic waste produced by households because it is used as the material in various commodities such as beverage bottles and food packaging (Figure 2). Plastic waste is dangerous because it is difficult to degrade in the soil as it may take 100 years or more (Setyowati and Mulasari 2013). Plastic waste causes problems for the community and may threaten the conservation area's ecosystem, especially in the coastal area's mangrove ecology. This can be seen from field observations where plastic is the dominant waste found in the TNBS mangrove area. If the condition of waste is allowed to continue and worsens, it can damage the ecosystem. Micro-plastic can reduce the environment's quality and cause physical damage and death of marine fauna (Wang et al. 2016; Sun et al. 2017; do Sul and Costa 2014). Plastic trapped by pneumatica or mangrove breath roots and root supports can be a physical barrier affecting the tree itself and its associated fauna, by preventing gas exchange and releasing harmful chemicals absorbed by the roots or industrially added to plastics (Cole et al. 
2011). Reducing the impact of waste, especially plastic waste, requires waste management to manage it properly and even might bring added value to society, such as recycling plastic waste into a new product or plastic raw material.

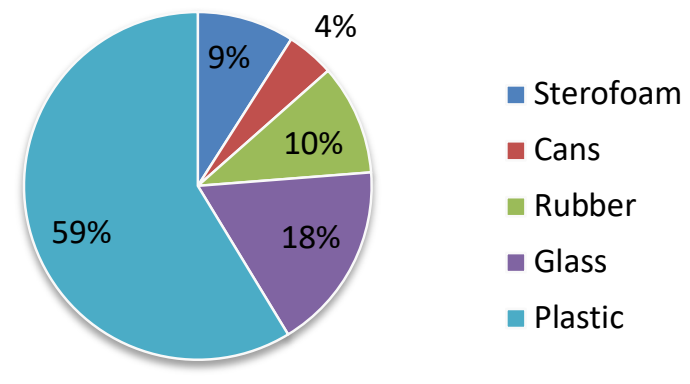

Figure 2. Inorganic waste in Sei Sembilang Hamlet.

Organic waste produced by the community is in the form of household food waste. People can utilize organic waste to produce compost. However, in Sei Sembilang Hamlet, the people do not feel the need for compost because planting is not part of their activities. Nevertheless, with a good education, the people will understand that planting is not only performed in a large-scale land. However, they can also be done on the household scale, i.e., in a limited space at home, such as planting fruits in pots (tabulapot) or other household needs plants such as chili and vegetables.

Most of the household waste generated by respondents is $1-3 \mathrm{~kg}$ in weight (Figure 3 ). The weight of this household waste is influenced by several factors, including the number of household members of the respondents. The greater number of household members, the more massive waste will be produced. The more massive household waste will put heavier pressure on the mangrove ecosystem in the BSNP area. Therefore, an effective waste management model to control the community's quantity of waste is needed.

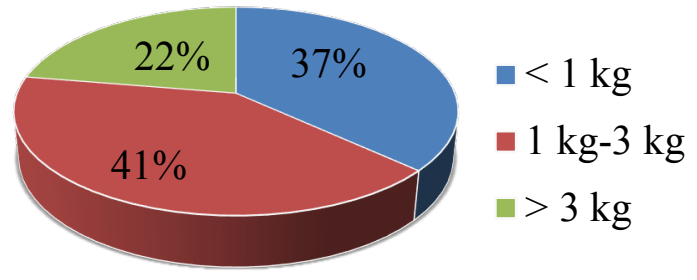

Figure 3. The average household weight on a daily basis.

The results showed that people's frequency of throwing waste every day is mostly once a day (Figure 4). The waste is disposed of under the houses which will be carried along by the river when high tide. The waste disposal time cannot be determined, as the respondents usually collect their waste first before disposing of it. However, some of the respondents directly dispose of their waste without collecting it in advance. This is commonly done by respondents who live not far from the riverside, as the waste disposed of will be directly carried away by the river. The frequency and behavior of people who throw garbage into the river resulted in the dirty river that can inhibit mangroves' growth. Plastic waste trapped in vegetation will cause the Christmas tree effect (Williams and Simmons 1996). Plastic waste can also cause the death of mangrove seedlings (Sidik 2016). Some respondents who collect the wastes have also performed waste sorting in their household. They sorted the wastes into organic and inorganic wastes. Inorganic waste that they collect are plastics garbage such as bottles or used plastic cups for a drink. The plastic waste collection is carried out to sell it. 


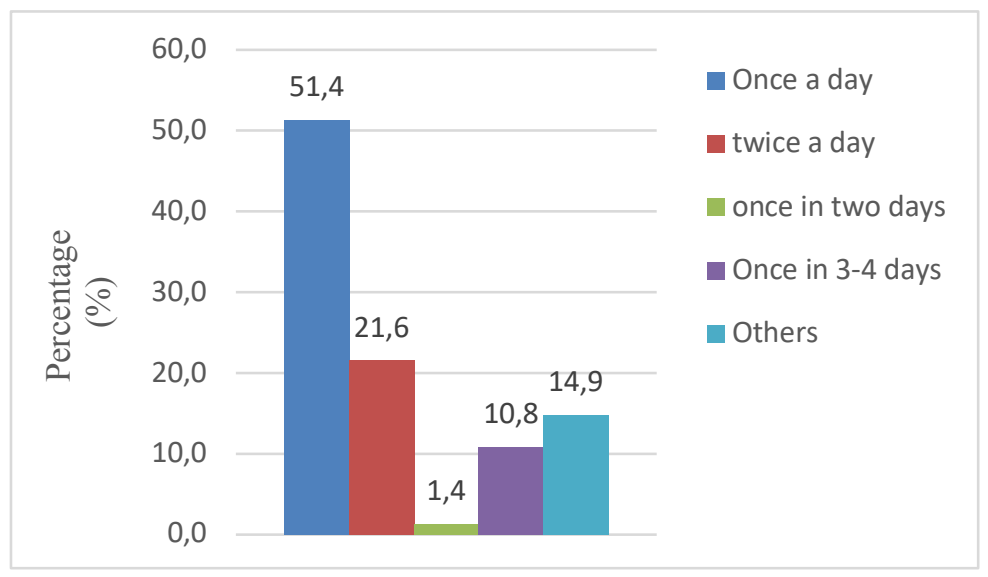

Figure 4. Frequency of respondent disposing of household waste.

\section{Social and Economic Characteristics of Sei Sembilang Hamlet Community}

The community's social and economic characteristics are a general description of the people's socio-economic life in Sei Sembilang Hamlet during the study. The social and economic characteristics in this study include the age, number of household members, the latest education, type of work, and income (Table 3). The social and economic characteristics need to be considered as daily waste products cannot be separated from every human life activity. Particularly for household waste, it is also related to the income level, educational level, and family size (Putra and Amaluddin 2019).

Table 3. Social and economic characteristics of Sei Sembilang Hamlet community.

\begin{tabular}{lccr}
\hline $\begin{array}{l}\text { Characteristics of } \\
\text { Respondents }\end{array}$ & Classification & Frequency & $\begin{array}{c}\text { Percentage } \\
\text { (\%) }\end{array}$ \\
\hline Age (years) & $20-30$ & 15 & 19.7 \\
& $31-40$ & 30 & 39.5 \\
& $41-50$ & 17 & 22.4 \\
Number of Family & $51-60$ & 8 & 10.5 \\
Members & $61-70$ & 6 & 7.9 \\
(person or individual) & $1-3$ & 10 & 13.2 \\
& $4-6$ & 42 & 55.3 \\
Education & $7-9$ & 22 & 28.9 \\
& $10-12$ & 2 & 2.6 \\
& None & 6 & 7.9 \\
& Elementary School (SD)/equal & 45 & 59.2 \\
Type of Job & Junior High School (SMP)/equal & 15 & 19.7 \\
& Senior High School (SMA)/equal & 7 & 9.2 \\
& University & 3 & 3.9 \\
& Fisherman & 25 & 32.9 \\
& Farmer & 0 & 0.0 \\
Income & Trader & 12 & 15.8 \\
& Housewife & 14 & 18.4 \\
& Entrepreneur & 6 & 7.9 \\
& Warehouse worker & 2 & 2.6 \\
& Unemployed & 4 & 5.3 \\
& Others & 13 & 17.1 \\
& IDR 0 - IDR 1,500,000 & 41 & 53.9 \\
& IDR 1,500,001 - IDR 3,000,000 & 14 & 18.4 \\
& IDR 3,000,001 - IDR 4,500,000 & 5 & 6.6
\end{tabular}




\begin{tabular}{lccc}
\hline $\begin{array}{l}\text { Characteristics of } \\
\text { Respondents }\end{array}$ & Classification & Frequency & $\begin{array}{c}\text { Percentage } \\
(\%)\end{array}$ \\
\hline & > IDR 4,500,000 & 16 & 21.1 \\
\hline
\end{tabular}

The average age of the respondents at the study location is 31 up to 40 years old. This indicates that the average respondents are at a productive age, where the productive age according to the Central Bureau of Statistics is ranging between 15 until 55 years old. At the productive age, people still have maximum energy in carrying out their activities. The average age of respondents ranges from 31 up to 40 years old, which also shows that the community has sufficient knowledge based on their experience. In general, age is directly proportional to experience and knowledge. The higher the person's age, the more experience he has, and the higher level is his knowledge.

Most respondents have $4-6$ members in the family $(55.3 \%)$. The number of family members affects the amount of waste generated in the household. The higher number of household members, the more waste will be produced (Kadir and Mardiana 2015). This is directly proportional to the household needs, where the higher number of family members, the more household needs are required to generate more waste.

The average education level of people in Sei Sembilang Hamlet is at the Elementary School (SD) level of 59.2\% and Junior High School (SMP) level of 19.7\%. This indicates that the level of knowledge of Sei Sembilang Hamlet people is still relatively low. Education is an essential factor in waste management. The higher the level of a person's education, the easier to accept new things so that it will be easier to complete it (Slamet 1989). Education is also closely related to technical mastery. The higher education of the people, the easier it will be to introduce waste management technology to improve waste management.

The main occupation of the majority Sei Sembilang Hamlet people is as a fisherman. This is because Sei Sembilang Hamlet is located on the Sembilang riverbank, which is directly adjacent to Sumatera's eastern sea and is an area of BSNP. Besides fishermen, some people also have jobs as traders. Access to this location is quite challenging; therefore, trading is one of the most promising jobs in Sei Sembilang Hamlet.

Most people are classified as the low-income community, with an average monthly income of IDR $1,500,000$. This is because most people rely on the work as fishermen without fixed income. An uncertain condition of the sea and weather and seasons to catch fish become obstacles for the people to catch.

\section{Knowledge, Attitudes, and Behavior on Waste and Its Management}

\section{Community knowledge related to waste and its management}

Knowledge is a preliminary stage when someone starts to recognize and understand something. Knowledge and attitudes of a person will play a role in the actions taken (Luh et al. 2017). The result indicates that community knowledge levels, both men and women, are relatively high, with a score of 80.04 and 81.29 , respectively (Table 4).

Table 4. Level of community knowledge in Sei Sembilang Hamlet.

\begin{tabular}{|c|c|c|c|c|}
\hline \multirow[b]{2}{*}{ No } & \multirow{2}{*}{ Indicator } & \multicolumn{2}{|c|}{ Score } & \multirow{2}{*}{$\begin{array}{l}\text { Community } \\
\text { average score }\end{array}$} \\
\hline & & Men & Women & \\
\hline 1 & General knowledge on waste & 100.00 & 100.00 & 100.00 \\
\hline 2 & Knowledge on waste impact & 81.58 & 84.21 & 82.88 \\
\hline 3 & Knowledge on waste sorting & 84.21 & 85.09 & 84.65 \\
\hline 4 & Knowledge on waste processing & 42.11 & 42.11 & 42.11 \\
\hline 5 & Knowledge on waste recycling & 80.26 & 81.58 & 80.92 \\
\hline \multirow[t]{2}{*}{6} & Knowledge on waste final processing & 92.11 & 94.74 & 93.43 \\
\hline & Average & 80.04 & 81.29 & 80.67 \\
\hline
\end{tabular}


All respondents have a general knowledge of waste, its origin, and type. However, the study result indicates that women have a better level of knowledge than men. Women's knowledge of the waste impact, waste sorting, waste recycling, and waste final processing have a higher score than the men's knowledge (Table 5).

Table 5. Level of community knowledge based on gender.

\begin{tabular}{lccccccc}
\hline Gender & $\begin{array}{c}\text { General } \\
\text { knowledge }\end{array}$ & Impact & Sorting & Processing & Recycling & $\begin{array}{c}\text { Final } \\
\text { Processing }\end{array}$ & Average \\
\hline Male & 50.0 & 49.21 & 49.23 & 50.00 & 49.18 & 49.29 & 49.48 \\
Female & 50.0 & 50.79 & 50.77 & 50.00 & 50.82 & 50.71 & 50.52 \\
\hline
\end{tabular}

The results revealed that women have higher knowledge than men, which indicates that women cannot be separated from nature. The position of women, mostly at home, causes greater interaction with waste than men. Women's understanding of waste issues make them more responsive to their environment. Women are change agents and greatly influence the environment quality (Wijayanti et al. 2019). At the social level, waste can also cause decreasing awareness in the community. The level of public awareness is decreasing, as seen from the lack of mutual concern among the society related to waste. Littering has been considered common practice among the community.

Economically, the community believes that waste can impact fish catches. Catching fish will decrease due to the increasing amount of waste. Waste can also disrupt the tourism sector. The area's dirty condition will reduce tourists' interest in visiting mangrove areas around Sei Sembilang hamlet. Tourists often visit Sei Sembilang Hamlet for mangrove tourism and migrant bird observation. The Sei Sembilang Hamlet community is also worried that the littering habit will be done continuously and become the public's culture, which will be part of the future generations. It can harm the behavior and culture of the community in the future.

In terms of knowledge of waste sorting, waste recycling, and waste final processing, most people have a relatively high level of knowledge. The community understands that waste consists of garbage that can rot and cannot rot. People also know about the type of waste that can be recycled, such as plastic, paper, and cans. People know that there are currently Waste Banks in Sei Sembilang Hamlet where they can buy, store, or reprocess plastic waste. However, waste bank activities have not been running effectively. Based on discussion, it is known that the program implemented was not preceded by an in-depth introduction to the social condition of the Sei Sembilang community. The characteristics of the people who mostly work as fishermen are accustomed to instant income, where they can immediately receive the money after returning home from fishing. While the program performed cannot bring instant results.

Hamlet's condition is not easily accessible, causing people to process the generated waste. However, their level of knowledge on waste processing is still relatively low. It is easier for them to dispose of the waste directly to the river than to process it. The community believes that waste processing activity, such as processing waste into compost, is unnecessary. This is because the primary profession among Sei Sembilang Hamlet community is a fisherman, not a farmer who needs compost to grow crops.

\section{Community attitudes regarding waste and its management}

Attitude is an emotional or affective assessment and cognitive component, such as knowledge of an object (Setyowati and Mulasari 2013). the community attitude related to waste management, both men and women have a very high or almost similar score, i.e., 92.74 and 92.83, respectively (Table 6). Men have higher attitudes towards waste transport and waste sorting, while women have higher scores towards waste recycling and processing. However, 
the different attitudes between men and women are not too much different. The average difference between men and women's attitudes are less than 1\% (Table 7). This indicates that men and women have equality in attitude. The interaction of women with waste is higher than men, making women have a higher awareness of the importance of a clean environment. Women are responsible for themselves and their domestic matters, especially their family's health. Therefore, knowledge of waste's impact will be a valuable lesson for women to take concrete action in protecting the environment.

Table 6. Community attitudes regarding waste management.

\begin{tabular}{llccc}
\hline \multirow{2}{*}{ No } & \multicolumn{1}{c}{ Indicator } & \multicolumn{2}{c}{ Score } & $\begin{array}{c}\text { Community } \\
\text { average score }\end{array}$ \\
\cline { 3 - 4 } & & Men & Women & 98.03 \\
1 & Waste collection & 98.03 & 98.03 & 71.55 \\
2 & Waste generation restriction & 71.55 & 71.55 & 98.36 \\
3 & Waste transport & 98.68 & 98.03 & 96.05 \\
4 & Waste sorting & 96.71 & 95.39 & 96.05 \\
5 & Waste reuse & 96.05 & 96.05 & 94.11 \\
6 & Waste recycling & 93.42 & 94.74 & 95.40 \\
7 & Waste processing & 94.74 & 96.05 & 92.79 \\
& $\quad$ Average & 92.74 & 92.83 & \\
\hline
\end{tabular}

Table 7. Community attitude regarding waste management based on gender.

\begin{tabular}{lcccccccc}
\hline Gender & Collection & $\begin{array}{c}\text { Generation } \\
\text { restriction }\end{array}$ & Transport & Sorting & Reuse & Recycling & Processing & Average \\
\hline Male & 50.00 & 50.00 & 50.67 & 51.35 & 50.00 & 49.30 & 49.32 & 50.09 \\
Female & 50.00 & 50.00 & 49.33 & 48.65 & 50.00 & 50.70 & 50.68 & 49.91 \\
\hline
\end{tabular}

Most people, both men and women, agree that waste must be disposed of properly and managed every day. Waste management needs to be performed in order to overcome household waste issues. It requires waste sorting between organic waste, inorganic waste, non-recyclable waste, and recyclable waste before final transport. Managing the amount of waste with the $3 \mathrm{R}$ principle (reuse, reduce, and recycle) is an efficient way to mitigate household waste issues.

Community behavior regarding waste and waste management

Behavior is any action or reaction of individuals towards the stimulation or environment (Depdiknas 2001). The results indicate that majority of the community, both men and women, have a relatively low level of behavior with a score of 39.04 and 41.89, respectively (Table 8). In general, the behavior is influenced by perception, attitude, and knowledge of people. Good knowledge, attitude, and perception will result in good behavior, and vice versa. However, the results indicate that even though the community's level of knowledge and attitude is relatively high, it is not followed by good behavior related to waste management.

Table 8. Community behavior on waste management.

\begin{tabular}{llccc}
\hline No & \multicolumn{1}{c}{ Indicator } & Men & Score & $\begin{array}{c}\text { Community } \\
\text { average score }\end{array}$ \\
\cline { 3 - 4 } & & 43.42 & Women & 43.42 \\
\hline 1 & Waste disposing habit & 52.63 & 43.42 & 51.32 \\
2 & Waste collection & 47.37 & 50.00 & 49.98 \\
3 & Waste sorting & 15.79 & 52.63 & 19.74 \\
4 & Waste utilization & 42.11 & 23.68 & 42.11 \\
5 & Waste transport & 42.11 &
\end{tabular}



6 Participation
32.89
39.47
36.32
Average
39.04
41.89
40.46

Community behavior is relatively low due to the geographic location of Sei Sembilang Hamlet, which is difficult to reach, and no adequate infrastructure related to waste management. This is in accordance with Harun (2017) research, which states that one of the factors influencing someone with good knowledge but poor behavior on waste management is the facilities and infrastructure to manage the waste. The community's high knowledge and attitude without facilities and infrastructure for waste management, such as temporary landfills, forces people to misbehave regarding waste. Lack of facilities and infrastructure improvement, in the long run, leads the poor behavior to become a culture among the community.

Even though the community attitudes are low, women have better behavior than men, particularly waste sorting, waste utilization, and participation in waste-related activities (Table 9). This is due to the nature of women accustomed to using waste that can be reused for other functions, such as reusing jam containers to be spice containers. This is in accordance with the study performed (Wijayanti et al. 2019), stating that women are the change agents with a major influence on the environment quality. Women can do many things concerning environmental management, including their interest in utilizing household garbage or waste into valuable economic items.

Table 9. Community behavior regarding waste management based on gender.

\begin{tabular}{lccccccc}
\hline Gender & Waste disposal & Collection & Sorting & Utilization & Transport & Participation & Average \\
\hline Male & 50.00 & 51.28 & 47.37 & 40.00 & 50.00 & 46.43 & 47.51 \\
Female & 50.00 & 48.72 & 52.63 & 60.00 & 50.00 & 53.57 & 52.49 \\
\hline
\end{tabular}

In terms of the participatory level, women also have a better score than men as their position are often at home, so they have a greater opportunity to participate than men. In addition, men's activities at sea are sufficiently draining, causing men to be reluctant to participate in waste management related activities. Therefore, the government and related parties' participation is essential to embrace all levels of society.

Littering behavior in the community has become an inherited habit passed down for men and women. Even though most people carry out waste collection and waste sorting, waste disposal is still done directly to the river. Most people perform plastic waste sorting in the form of a bottle or used drink cup to be sold to the waste bank. The utilization of waste, such as organic waste for composting, is not carried out by most people in Sei Sembilang Hamlet. This is because the main occupation in this village is fishermen not farming, so composting is an unnecessary activity. The utilization of waste for other products is also not done because the community does not know about it. The use of waste by the community is only reusing the waste (reuse) for other uses, such as using used jam bottles to store spices.

The community does not carry out the waste transport to temporary garbage collection. This is because Sei Sembilang Hamlet still does not have a temporary landfill. This shortage should be a priority for the local government. Such programs as the provision of trash bins have been carried out, however with the lack of waste collection and transport, the program will be useless because in the end, the waste will be disposed to the river. The participation level of the community in the program related to waste management is also relatively low. The government should evaluate such a program. Lack of community participation may occur due to the timing of program implementation. For example, it is held when most people are at sea or lack initiative from the government to involve the community.

Based on the above mentioned, it can be concluded that the community behavior in Sei Sembilang Hamlet is not only influenced by the knowledge and attitude of the people but also by the condition of Sei Sembilang Hamlet. Community behavior can be improved if adequate 
and suitable waste disposal facilities are in place so that the government encourages people not to litter and provide solutions in the form of adequate waste disposal facilities.

\section{Waste Management Model}

Based on the results described above, an integrated waste management model is developed in the form of a multi-stakeholder partnership by involving the community and relevant parties, i.e., BSNP and local government representatives. A multi-stakeholder partnership is a partnership developed by various parties to achieve common goals by sharing roles, responsibilities, resources, and benefits and sharing risks. The direction and spirit of partnership are contained in Presidential Regulation Number 59 of 2017 and Regulation of the Minister of National Development Planning / Head of Bappenas Number 7 of 2018.

The community develops the management model. The model generated can accommodate all community layers and involve multi-stakeholders to achieve an integrated waste management model. The management model scheme is presented in Figure 5. Based on the design model developed by the Sei Sembilang Hamlet community on participatory waste management and alternative ecotourism development, it can be concluded that the model desired by the community is an integrated model that does not only accommodate all levels of society but also drives the sharing of roles between the community, government, and the private sector. The roles of each party can be described as follows:

\section{Community roles}

The community plays a vital role in waste management. Education awareness and community skills for waste management by applying the principles of reducing, reuse, recycling, and replace (4R) are essential in solving waste issues through waste management from the source (Asteria and Heruman 2016). Therefore, the first step that can be taken in managing household waste in the community is to establish self-help hygiene in each hamlet. This establishment should be strengthened by the village's decree and supported by the Village Regulation (Peraturan Desa). Several community organizers manage the self-hygiene program through the Waste Bank that manages operations, personnel, and financial management. Waste Bank will become a business unit of Sembilang Maju Bersama Cooperatives, as the only existing cooperative in Sei Sembilang Hamlet. By establishing a waste bank to be part of the business unit, the cooperative will have a clear control system over the waste bank.

The operational management system consists of sorting, collecting, picking, transporting, and managing prior to the final disposal. The sorting activities are carried out by dividing waste based on type. Waste is divided into organic and inorganic waste. This activity must be socialized to the community, considering that households' garbage has not been appropriately managed. Waste that has been sorted requires a follow-up where it can be processed by recycling. Organic waste can be recycled into compost, while the inorganic need to have resorted to be reused. Inorganic waste is divided into two parts, i.e., waste that can be recycled in a garbage bank, and waste that can be used as other products. Recyclable waste is collected to be transported to the waste bank. Final disposal activities are the responsibility of the Waste Bank. In contrast, each hamlet area's collecting activities are carried out by empowering the community to maintain their respective environments' cleanliness.

In every operational system conducted, it requires the division of roles in society. The division of roles in the cleanliness operational system is expected to reflect a sound coordination system. The division of roles must involve the active role of the community, both men and women. Women's involvement in waste management projects will empower women because they have the basic nature of caring for and maintaining environmental cleanliness, especially if the project activities are linked to activities that increase income and productive resources (Harningsih 2010). Women's empowerment that can be developed in this management model is the sorting waste process and processing waste at the household level. 


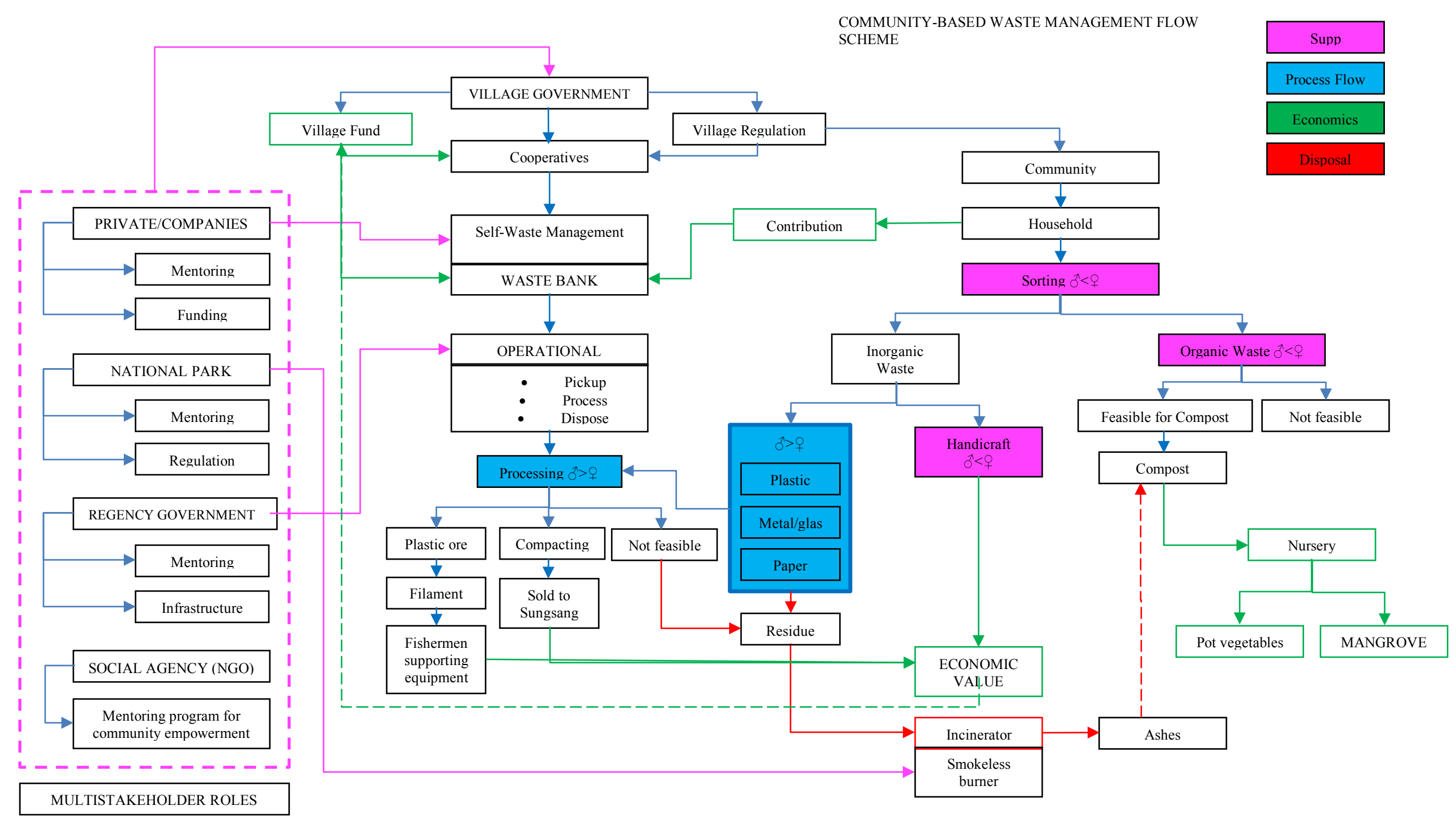

Figure 5. Integrated waste management model scheme. 
At this stage, women have a role in utilizing waste into other products. Inorganic waste can be recycled into other products such as crafts, and organic waste can be processed into compost. A small number of women already have this skill, but it is still minimal. Some women in Sei Sembilang Hamlet have been able to utilize drink bottles into small chairs, or sed oil bags for small bags, but their capabilities are still limited. Therefore, the government's role is vital to improve the community's capability, especially women in recycling waste into handicraft products (Figure 6).

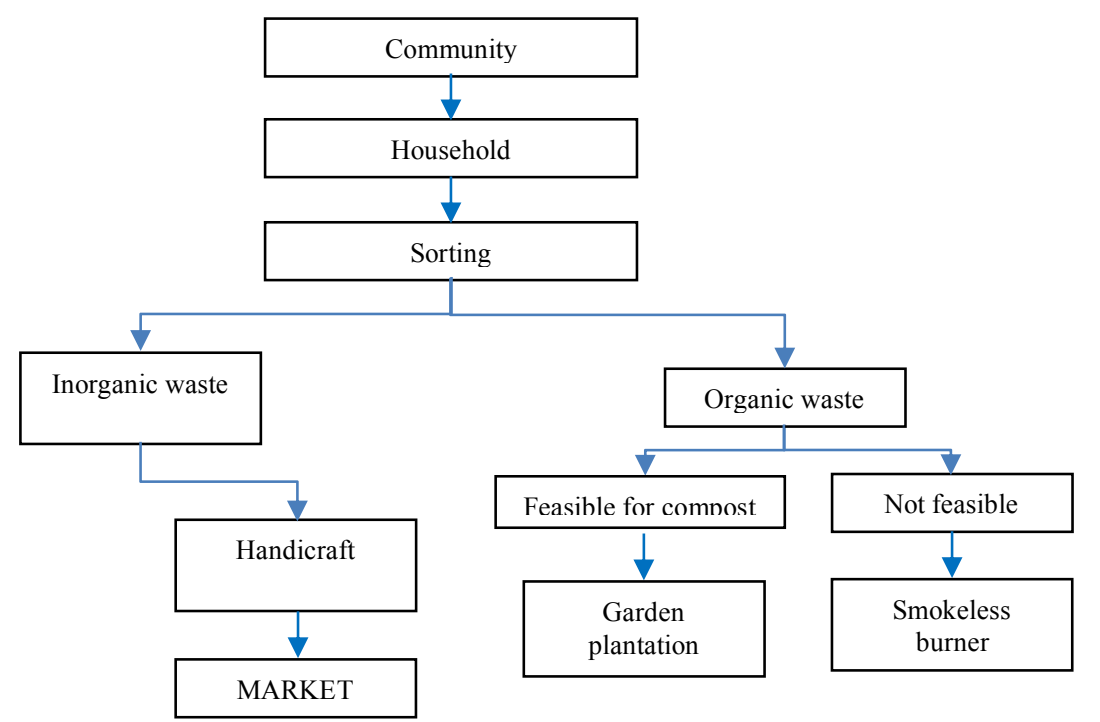

Figure 6. Women's roles in waste management.

For organic waste that is processed into compost, women can use it to create a small plantation in the gardens. They can grow family needs plants such as chili and vegetables using polybags arranged to avoid space consumption. Compost can also be used for gardening family medicinal plants. For women to play a leading role, human resources development is important through training and assistance carried out by the government and private sector. Furthermore, inorganic waste that cannot be recycled into handicraft products will be taken to the Waste Bank to be recycled into economically valuable raw materials, such as plastic ores. This opportunity can be an alternative income for the Waste Bank manager. For example, plastic waste that is processed into plastic pellets can be processed into materials for fishermen's supplies such as buoys, toolboxes, plastic ropes, and even alternative fuels in the future. At this stage, men have higher roles than women (Figure 7).

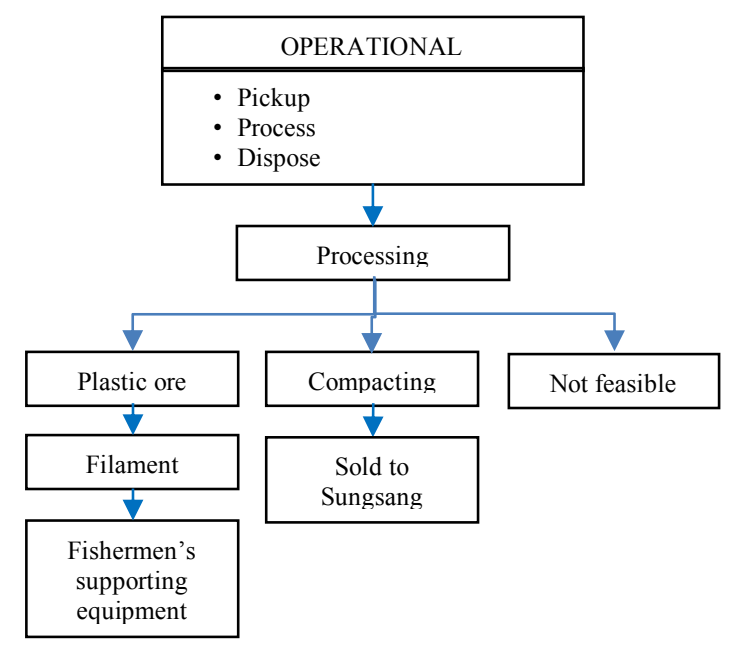

Figure 7. Men's roles in waste management. 
Men play a role that relies on strength, such as transport, processing up to sales. Therefore, the management of the waste bank will be executed more by men. However, this does not mean that women cannot participate in waste bank operations. Women can play a role in the waste bank as financial or administrative staff. Women are generally familiar to manage finance and administration. Women are most familiar with finance and administration management, so it is expected that they can support the administrative system of the waste bank in an orderly manner. If the self-hygiene activity can be carried out correctly in the hamlet area, it will reduce waste disposal violations, particularly waste disposal underneath the houses or Sembilang river.

The community can also process plastic into a net placed as a fence underneath the house. The net serves to hold waste in the river to identify the source of waste in the river. This may become the measure of public awareness in Sembilang hamlet, through the volume of waste entangled in the net. The removal of waste held back in the net can be executed together periodically by each hamlet community's residents. Through relevant institutions (KLHK through BSNP Office or Environmental Office of Banyuasin Regency), the government can provide technical assistance in the form of facilities and infrastructure.

All efforts to manage the cleanliness of settlement and river within the mangrove forest area are carried out by the community as described above. This indicates the active participation of the community, which starts from small scale activity within their area. A community must be involved starting from the initial plan, execution, and supervision. Such a level of participation can be categorized as the highest level of community strength or participatory level (Arnstein 1969).

\section{Government roles}

Waste management activities carried out independently is a form of active participation from the community. Government and related institutions shall support and provide direct coaching to the environmental hygiene management institution. The government must also socialize regulations concerning environmental hygiene according to the characteristics of the hamlet area. Effectiveness of socialization can be implemented through regular meetings conducted by BSNP, either in Sembilang hamlet or Sungsang 4 village.

Also, the village government is expected to stipulate a village regulation to encourage the initiatives, movements, and participation of the village community to develop village potential and assets for mutual prosperity. The regulation is also a form of responsibility of the village government that is professional, efficient, effective, open, and responsible in responding to environmental issues. Through the village regulation, the village government can also improve public services for the citizens of the village community to accelerate the realization of public welfare. The district government can also support by adjusting regulations and appropriate assistance according to geographical conditions.

The weakness of the current government is low law enforcement and the low performance of the authorities. Therefore, it requires policy to improve the authorities' performance to enforce the stipulated regulation and improve coordination among institutions. To achieve sustainable development, the government must consider the environmental aspect of each policy and decision made. This is crucial to improve the government's role in handling waste in the mangrove forest and preserving it. Initiative to develop mangrove ecotourism requires support in order to maintain the preservation of the mangrove forest. To improve the role, the government should act as the facilitator to the community and other related parties. This indicates a paradigm of development, in which the decision of development is integration between community aspiration (bottom-up) and government policy (top-down).

To support the operations of the waste bank, the village government can use the village fund. Village funds can be planned through the Village Medium Term Development Plan as part of village economic development. The fund can be delivered through cooperatives as the 
channel of waste bank business activities or directly managed by the waste bank itself. Similarly, to develop ecotourism of mangrove forests, the village government needs to formulate a new policy to support the program. The policy made should be aligned, supporting each other, and strengthen the existing policy of Berbak and Sembilang National Park Center. With the policy, it is expected that the mangrove ecotourism initiative can encourage public awareness to strengthen the preservation of Sembilang mangrove forest function.

\section{Roles of private sector and relevant parties}

The waste management activities in a mangrove forest require high commitment and coordination with the government, the community, and other relevant parties. All parties have their respective vital roles, as well as the private sector. One of the private parties that can play a role in waste management is the Non-Government Organization (NGO), a non-governmental organization mostly engaged in environmental sectors.

Auliya et al. (2020) stated that in accordance with the Minister of Home Affairs Regulation Number 15 of 2009 concerning Guideline of the Cooperation between Ministry of Home Affairs and Non-Governmental Foreign Institutions, the NGO might have two major roles, i.e.: 1) Empowerment, that is carried out through organizing and assisting program implementation, either program of policy from the government or likewise. However, it should still be in line with the objectives to be achieved. 2) Advocacy, which drives the awareness of the government policies' rights and control that will impact the community. According to Willis (2011), NGOs' roles, particularly in developing the low level of community, are orienting or referring to: public welfare and services provision; emergency assistance; educational development; participation and empowerment; self-sufficiency; advocacy; and network.

NGO can increase community capacity to improve the welfare, for example, by providing facilities and infrastructure that can support the community in waste management such as providing trash bins or funding support to procure recycling equipment for plastics waste. Community empowerment is required to improve human resources capacity and increase community participation in waste management. For other private parties such as companies to increase their sensitivity and concern towards the environment, they can build partnerships with the community. Regional governments or NGOs can facilitate the partnership. In this case, the private company may provide facilities to execute Waste Bank programs in Sei Sembilang Hamlet, such as funding assistance or other products that can attract the community to increase their participation in waste management, for example, by providing a reward of certain products for the community who trade their garbage in the waste bank.

\section{CONCLUSIONS}

The knowledge and attitude of the Sei Sembilang Hamlet community are relatively at a high level; however, it is not followed by the behavior. The community behavior is low due to the geographical location of Sei Sembilang Hamlet that is difficult to reach, and lacks adequate facilities and infrastructure for waste management; thus, the community does not have the right option. Women tend to have a higher level of knowledge, attitude, and behavior than men because they are responsible for themselves and any domestic matters at home, particularly the family's health. Knowledge of the waste impact can become the lesson for women to take tangible action in preserving the environment. The waste management model developed in Sei Sembilang Hamlet is an integrated waste management model that accommodates all layers in the community and shares roles among the community, government, and the private sector. In this model, women play a more significant role in waste sorting and 
plastic waste recycling into handicraft products. Men play a role in waste transport and plastic waste processing into economically valuable plastic raw materials. It requires a mentoring program, particularly for the women, to improve their production capacity in producing wastebased handicraft products. Women's involvement is required as waste management tends to be more effective and efficient when involving more women. It requires a strong commitment from the Sungsang 4 Village Government in applying the $3 \mathrm{R}+\mathrm{P}$ concept to create a clean and healthy environment, which can be set out in a village regulation (Peraturan Desa) concerning waste. It requires policy from the Banyuasin Regency Government to drive sustainable crosssector partnerships.

\section{ACKNOWLEDGEMENTS}

We would like to express our gratitude to the ZSL-KELOLA Sendang for facilitating the data collection for this study.

\section{REFERENCES}

Arnstein, S. R. 1969. A ladder of citizen participation. Journal of the American Planning Association 35(4): 216-224.

Asteria, D., and Heruman, H. 2016. Bank sampah (Waste banks) as alternative of communitybased waste management strategy in Tasikmalaya. Human and Environmental Journal (Jurnal Manusia dan Lingkungan) 23(1): 136-141.

Auliya, A. N., Choirunnisa, E., and Arif, L. 2020. Peran Lsm Spektra Dalam Mutualism Partnership Program Bank Sampah. Jurnal Ilmu Administrasi \& Sosial 9(1): 52-66.

Cole, M., Lindeque, P., Halsband, C., and Galloway, T. S. 2011. Microplastics as contaminants in the marine environment: A review. Marine Pollution Bulletin Elsevier Ltd 62(12): 2588-2597. DOI: 10.1016/j.marpolbul.2011.09.025

Cresswell, J. W. 2016. Research Design Pendekatan Metode Kualitatif, Kuantitatif dan Campuran. Pustaka Pelajar, Yogyakarta.

Depdiknas. 2001. Kamus Besar Bahasa Indonesia. Jakarta: Balai Pustaka.

Harningsih, T. 2010. Peran Gender dalam Menangani Permasalahan Sampah. Jurnal Kesetaraan dan Keadilan Gender 5(2).

Harun, H. 2017. Gambaran Pengetahuan dan Perilaku Masyarakat Dalam Proses Pemilahan Sampah Rumah Tangga Di Desa Hegarmanah. Jurnal Aplikasi Ipteks untuk Masyarakat 6(2): 86-88.

Kadir, H., and Mardiana. 2015. Analisis willingness to pay (WTP) sampah rumah tangga (studi kasus perumnas kelurahan simpang baru panam pekanbaru). JOM FEKON 2(1): 1-16.

Kastaman, R., Kramadibrata, A. M., and Melawati, M. 2007. Sistem pengelolaan reaktor sampah terpadu Silarsatu. Humaniora, Bandung, Indonesia.

Krejcie, R. V., and Morgan, D. W. 1970. Determining Sample Size For Research Activities. Educational and Psychological Measurement 30(3): 607-610. DOI: 10.1261/rna.2763111

Luh, N., Sukerti, G., Sudarma, I. M., Pujaastawa, I. B. G., East, A. T., District, D., Town, D., and Province, B. 2017. Perilaku Masyarakat Dalam Pengelolaan Sampah Dan FaktorFaktor Yang Mempengaruhi. Journal ECOTROPHIC 11(2): 148-155.

Patuwo, N. C., Pelle, W. E., Manengkey, H. W. K., Schaduw, J. N. W., Manembu, I. S., and Ngangi, E. L. A. 2020. Karakteristik Sampah Laut di Pantai Tumpaan Desa Tateli Dua Kecamatan Mandolang Kabupaten Minahasa. pesisir dan Laut Tropis 8(1): 70-83. 
Putra, A., and Amaluddin, L. O. 2019. Perilaku Masyarakat Dalam Membuang Sampah Rumah Tangga Di Kelurahan Wali Kecamatan Watopute. Jurnal Penelitian Pendidikan Geografi 4(2): 92-101. DOI: 10.4324/9780429463013-35

RECOFTC. 2015. Mainstreaming gender into forest policies in Asia and the Pacific. Fao \& Recoftc.

Setyowati, R., and Mulasari, S. A. 2013. Pengetahuan dan Perilaku Ibu Rumah Tangga dalam Pengelolaan Sampah Plastik. Kesmas: National Public Health Journal 7(12): 562. DOI: 10.21109/kesmas.v7i12.331

Sidik, H. 2016. Pengembangan hutan mangrove pesisir Bantul terkendala sampah. Antara News.

Singarimbun, M., and Effendi, S. 2019. Metode penelitian survai. LP3es.

Slamet, Y. 1989. Konsep-konsep dasar partisipasi sosial. Proyek Pengembangan Pusat Fasilitas Bersama Antar Universitas (Bank Dunia XVII). PAU Studi Sosial Universitas Gajahmada. Yogyakarta.

Su, Y. R., Fatmawati, F., and Ntelok, Z. R. A. 2019. Penguatan Partisipasi Perempuan dalam Pengendalian Resiko Kerusakan Lingkungan Hidup bagi Kelompok Ibu Rumah Tangga di Kelurahan Mbaumuku, Manggarai, Flores, NTT. International Journal of Community Service Learning 3(2): 75-82.

Sucipto, C. D. 2012. Teknologi pengolahan daur ulang sampah. Yogyakarta: Gosyen Publishing.

do Sul, J. A. I., and Costa, M. F. 2014. The present and future of microplastic pollution in the marine environment. Environmental pollution Elsevier 185: 352-364.

Sun, X., Li, Q., Zhu, M., Liang, J., Zheng, S., and Zhao, Y. 2017. Ingestion of microplastics by natural zooplankton groups in the northern South China Sea. Marine pollution bulletin Elsevier 115(1-2): 217-224.

Talalaj, I. A., and Walery, M. 2015. The effect of gender and age structure on municipal waste generation in Poland. Waste Management Elsevier Ltd 40: 3-8. DOI: 10.1016/j.wasman.2015.03.020

Wang, J., Tan, Z., Peng, J., Qiu, Q., and Li, M. 2016. The behaviors of microplastics in the marine environment. Marine Environmental Research Elsevier Ltd 113: 7-17. DOI: 10.1016/j.marenvres.2015.10.014

Wijayanti, I., Kusuma, N., and Pneumatica, O. 2019. Gerakan Ekofeminisme Dalam Pemberdayaan Perempuan Pengolah Limbah (Studi Kasus Komunitas Pengolah Limbah di Desa Narmada). RESIPROKAL: Jurnal Riset Sosiologi Progresif Aktual 1(1): 40-52. DOI: 10.29303/resiprokal.v1i1.4

Williams, A. T., and Simmons, S. L. 1996. The degradation of plastic litter in rivers: Implications for beaches. Journal of Coastal Conservation 2(1): 63-72. DOI: 10.1007/BF02743038

Willis, K. 2011. Theories and Practices of Development. Theories and Practices of Development. DOI: 10.4324/9780203844182

Winata, A., and Yuliana, E. 2016. Tingkat Keberhasilan Penanaman Pohon Mangrove (Kasus: Pesisir Pulau Untung Jawa Kepulauan Seribu). Jurnal Matematika, Sains, dan Teknologi 17(1): 29-39.

YPI. 2017. Profil Dusun Sei Sembilang, Desa Sungsang IV, Kecamatan Banyuasin II, Kabupaten Banyuasin, Provinsi Sumatera Selatan. Yayasan Puter Indonesia (YPI), Palembang, Indonesia. 